\title{
DIFFERENCES IN STRATEGIES BETWEEN RAPIDLY AND GRADUALLY INTERNATIONALISING POLISH FIRMS
}

\author{
Mirosław JAROSIŃSKI - Krystian BARŁOŻEWSKI
}

(Received: 29 May 2019; revision received: 4 November 2019;

10 November 2019)

\begin{abstract}
The paper presents a qualitative study of rapidly and gradually internationalising Polish firms. It compares these two types of firms with a special attention to their competitive strategies. The results show that there are more similarities than differences between the two groups of firms from emerging markets. These findings, based on case studies and interviews must be interpreted with a lot of caution, because the similar strategic behaviour of gradually internationalising firms to rapidly internationalising firms may stem from the fact that the former want to quickly reduce the distance to their counterparts in highly developed countries and thus take some strategic actions similar to rapidly internationalising firms.
\end{abstract}

Keywords: internationalisation, competitive strategies, Central and Eastern Europe

JEL classification indices: M16

Mirosław Jarosiński, corresponding author. Associate Professor at SGH Warsaw School of Economics, Faculty of World Economy, Institute of International Management and Marketing. E-mail: mjaros@sgh.waw.pl

Krystian Barlożewski, Associate Professor at SGH Warsaw School of Economics, Faculty of World Economy, Institute of International Management and Marketing.

E-mail: kbarlo@sgh.waw.pl 


\section{INTRODUCTION}

Firms entering foreign countries face different pressures from those found in the domestic market due to distinct configuration of market forces in the host countries. Additionally the companies going abroad may follow different internationalisation paths, i.e. they may expand gradually or rapidly. While occurrence of the latter companies was a nascent idea in the 1990s, today there are a lot of such firms found in many countries (Cavusgil - Knight 2015).

The emergence of rapidly internationalising firms is explained by a wide range of reasons including technological progress in transportation, manufacturing and communication; increasing homogeneity of customer preferences and firm strategies as well as many other factors. It is also argued that it is easier to internationalise rapidly than try to compete and increase market share in a highly competitive domestic market with a limited growth potential (Chetty - Campbell-Hunt 2004). Therefore it is argued that the rapidly internationalising firms should be observed in smaller countries more frequently (Cavusgil - Knight 2015; Bouncken, et al. 2015).

Despite the growing number of studies, some authors argue that there has been still little research on the differences between gradually and rapidly internationalising firms in terms of their strategic approach (Griffith - Cavusgil 2008), especially from the emerging economies like Poland (Śliwiński 2012). Indeed, it relates also to research on differences between rapidly internationalising firms from advanced economies and emerging markets (Peńa-Vinces et al. 2014; Cavusgil - Knight 2015). Other authors posit that more studies comparing "Born Globals", International New Ventures and non-exporters should be also conducted (Sikora - Baranowska-Prokop 2018).

Taking into consideration limited resources possessed, it might be argued that rapidly and gradually internationalising companies face different conditions even on the same markets. Additionally, as the conditional context of the developed economies differs from developing countries there might also be significant distinction stemming from it. As a result it may determine divergent competitive approaches of companies following different internationalisation paths. A vast majority of research so far was focused on developed markets (Peńa-Vinces et al. 2014). Thus, it would be interesting to find out what kind of competitive approaches are adopted by companies coming from the CEE region and what the differences between gradually and rapidly internationalising firms from that region are.

The importance of this topic and the necessity to make it a research subject was highlighted in the recent literature. For example, Grifith et al. (2008) consider as a primary category research question to explain how firms reconcile global standardisation objectives with local customisation needs and what the 
impact of standardisation/adaptation on firm performance is. Cavusgil - Knight (2015) stressed the potential benefits from examining differences between born global and traditionally internationalising firms where longitudinal surveys and case studies should be particularly useful. Śliwiński (2012) argued that more qualitative studies are needed for Polish companies as a vast majority of the extant research is quantitative, which does not allow for a proper understanding of behaviour of Polish companies going abroad. Trąpczyński (2013), on the other hand, added that more attention should be drawn on the link between the competitive approach and internationalisation strategy. Baranowska-Prokop - Sikora (2015) studied some aspects of competitive strategies of Polish "Born Globals". Those authors, in a later paper, came to the conclusion that there still exist large gaps regarding the international orientation of Polish companies that need to be addressed to allow further theory development (Sikora - Baranowska-Prokop 2018). Finally it must be noted that some authors call for further research focused on better understanding of the performance drivers of the internationalising companies in the context of building their competitive advantage (Rua et al. 2017).

Our study intends to address this missing link in the literature concentrating on the differences between rapidly and gradually (or incrementally) internationalising firms in terms of their competitive strategy. ${ }^{1}$

This paper is structured as follows. In the first section, the traditional incremental and the rapid process of internationalisation are discussed in the light of earlier research. Subsequently, the nature, types and dimensions of competitive strategies are introduced. In the following section differences between gradually and rapidly internationalising companies are highlighted. Further, the research method is described, followed by the analysis of case studies. The ensuing part of the paper is devoted to discussion of the obtained findings and their implications. The paper closes with some final concluding remarks.

\section{PATHS OF INTERNATIONALISATION - GRADUAL AND RAPID}

The most frequently described "Uppsala model of internationalisation" is based on the assumption that firms go abroad in incremental steps after they learn the conditional context in foreign markets, i.e. they collect necessary knowledge,

There is some controversy whether Poland can still be counted as an "emerging market". We found out that despite many changes, some institutions still qualify this country as an "emerging market", e.g. The MSCI Global Investable Market Indexes (GIMI) Methodology Country Classification (https://www.msci.com/market-cap-weighted-indexes as of Oct. $27,2019)$. Besides, some of the firms under study developed when it was undoubtedly an emerging market, so we believe that such a statement is justified. 
resources and experience (Johanson -Vahlne 1977). Therefore the model is often referred to as the 'stages model' (Chetty - Campbell-Hunt 2004) or 'incremental stages theory' (Bouncken et al. 2015). The model implies that firms' internationalisation is evolutionary. It takes several years from firm inception and the first time it is focused on neighbouring markets with short distance, not only in geographical, but also in cultural sense (Śliwiński 2012).

On the other hand, it was observed in the 1990s that more and more companies enter foreign markets immediately or soon after they are founded. Moreover, very quickly they start to develop export activities to a large extent (McDougall - Oviatt 1994). These companies were called International New Ventures (INVs) or "Born Globals" (BGs). Their behaviour was contradictory to the traditional process model of internationalisation. McDougall and Oviatt defined INVs as "business organizations that from inception seek to derive significant competitive advantage from the use of resources and the sale of outputs in multiple countries" (McDougall - Oviatt 1994).

Born Global firms are defined as companies which enter foreign markets early after they are founded and internationalise at a high speed, scope and degree, which differentiates them from traditional exporting firms and INVs (Bouncken et al. 2015). Born Global companies are usually associated with high-technology companies delivering specialised and customised products and services to customers from a specific global niche market (Chetty - Campbell-Hunt 2004). Although initially BGs were equalled to INVs this is no longer the case. Thus for the purpose of this paper both International New Ventures and Born Global firms will be referred to jointly as "rapidly internationalising firms".

Scholars provide several reasons for early internationalisation including rapid changes in manufacturing and communication technologies, shortening product life cycles, high research and development costs, increasingly international nature of industry competition (Andersson et al. 2014), emergence of global niche markets, and development of global networks and alliances (Cavusgil - Knight 2015).

\section{COMPETITIVE STRATEGIES - DEFINITION, TYPES, DIMENSIONS}

A competitive strategy is a set of tools and activities aimed at using company resources to achieve competitive advantage. This in turn should allow the company to reach an attractive competitive position (Pett et al. 2004; Gorynia 2004). The competitive strategy and position should be tailored to the country and industry environment. As the conditional context may vary from country to country, in the same way the favourable competitive positioning and competitive strategies 
of a single company may differ between markets (Roth - Morrison 1992). It is stressed in the literature that firms going abroad, especially born global firms derive their competitive advantage from the following sources: focus on innovations and entrepreneurial orientation even while growing rapidly; ability to retain technological leadership and agile organisation; active engagement in business networks and taking a reasonable risk while using opportunities (Cavusgil Knight 2015).

There might be at least three generic business level strategies: cost leadership, differentiation and focus on a specified niche market. Cost leaders are focused on efficiency, which is reflected by delivering products or services at the lowest cost and quality acceptable for a wide range of customers. That strategy might be pursued by low pricing, ensuring higher efficiency in production than competitors, controlling of overhead expenses, implementing cost reducing innovations, maintaining low levels of inventory and high capacity utilisation (Porter 1980; Roth - Morrison 1992; Pett et al. 2004).

Differentiators, on the other hand, are willing to offer unique products at a reasonable price (Porter 1980). There are generally two differentiation options, either through better marketing or product innovations. Marketing differentiation might be achieved through a distinguishing image, control of distribution channels, distinctive customer service, more advertising and promotion than competitors and innovative marketing techniques. Differentiation through product innovation requires developing new and specialty products, investments in new technologies and facilities as well as leadership in research and development efforts (Roth - Morrison 1992; Pett et al. 2004).

A common view is shared that international companies operating in different countries should tailor their business strategies to a given market. Therefore those companies should pursue 'country centred strategies'. This approach might be associated with gradually internationalising firms. However, born global firms need to compete on a global basis hence it is believed they should find and reach a favourable position in a global niche market (Roth - Morrison 1992).

When a company offers a wider range of products or services it might adopt divergent competitive strategies for each of the business unit, market segment or product. Additionally, it must be noted that each of the competitive strategies requires different organisational resources and arrangements, including staff, business processes, formal procedures, motivational systems, styles of leadership and even corporate cultures (Nayyar 1993).

Some scholars share the opinion that the Porter's framework might not be sufficient to meaningfully describe a company's competitive strategy (CampbellHunt 2000). As it was presented above, there are a lot of possible elements of competitive strategies. Therefore, to describe and compare competitive strategies 
Table 1. Dimensions of competitive strategies

\begin{tabular}{|l|l|}
\hline Quality reputation & Sales \\
- Reputation & - Advertising \\
- Product quality & - Promotional activities \\
- Service quality & - Sales force \\
\hline Marketing & Product innovation \\
- Advertising & - Level of prices \\
- Brand identification & - New products introduction \\
- Channel control & - Specialty products \\
- Marketing innovation & - Assortment breadth \\
& - Industrial design \\
\hline Operations & Market scope \\
- Quality control & - Product breadth (offering a narrow or broad \\
- Procurement & line of products to specific customer seg- \\
- Manufacturing innovation & ments) \\
- Operating efficiency & - Customer breadth (serving specific or vast \\
- Time to order fulfilment & geographical markets) \\
- Modern plants and entry modes & \\
\hline Organization & External relationships \\
- Flexibility & - Collaboration in the industry \\
- Firm's stability (financial resources) & - Ecology focus \\
- Skilled workforce & \\
- Entrepreneurial orientation & \\
\hline
\end{tabular}

Source: Own work based on Campbell-Hunt (2000: 138); Śliwiński (2012: 31).

for given companies a set of internal and external factors (strategy dimensions) must be analysed (Peńa-Vinces et al. 2014). The possible dimensions of competitive strategies are presented in Table 1.

It must be noted that according to resource based view resources which are possessed or controlled by those companies, e.g. knowledge, experience in foreign markets, staff with its level of education and skills, firm size, firm age, etc., play a significant role in explaining competitive strategies of internationalising firms (Peńa-Vinces et al. 2014). Trąpczyński (2013) adds that while advancing in the internationalisation process, different competitiveness dimensions will be relevant for a given company.

\section{LITERATURE REVIEW ON THE LINK BETWEEN COMPETITIVE STRATEGIES AND INTERNATIONALISATION PATH}

In reference to past studies, we now present differences between gradually and rapidly internationalising companies linked to particular dimensions of competitive strategies. 


\subsection{Type of competitive strategy (market focus and scope)}

The opinions of scholars on the types of competitive strategies followed by gradual and rapidly internationalising firms are inconsistent. Some argue that there are no differences between both groups of firms in terms of the strategy conducted (Harveston 2000; Kowalik et al. 2017). According to Harveston (2000), regardless of the internationalisation path the companies demonstrate a high level of responsiveness to country-level conditions. Other authors reason that there are evident differences between rapidly internationalising firms which focus on a specific niche, with narrowly defined customer groups and narrow product range, and the traditional companies pursuing less niche focused international strategy (Chetty - Campbell-Hunt 2004; Rialp et al. 2005).

There is, however, a common agreement in the literature that rapidly internationalising firms (and especially "Born Globals") are more likely to employ differentiation or focus strategy than cost-leadership strategy. Some argue that it is because a niche focus strategy will have a positive impact on firm performance as it is linked with targeting homogeneous market segments with standardised products (Moen - Servais 2002). According to others, those companies provide specialty and distinctive offering targeted to a limited number of customers due to limited resources (Chetty - Campbell-Hunt 2004; Cavusgil - Knight 2015). The latter is in line with the research conducted by Śliwiński (2012) on Polish rapidly internationalising firms whereby the most important factors of their competitive advantage are quality, technology and know-how.

Interestingly, usually the authors assume that there should be some differences relating to chosen path of internationalisation as it implies level of risk tolerance demonstrated by the firms' managers. Therefore a common expectation is that rapidly internationalising firms should be more risky and aggressive in their international strategies choosing global or transnational strategies. It is also assumed that traditional firms going abroad incrementally should be less risky and subsequently more likely to choose product standardisation strategy with very limited product adjustments. It should help them to use economies of scale and ensure best utilisation of their resources (Harveston 2000). On the other hand, recent research shows that the rapidly internationalising companies may reduce their business risk by following an industry recipe understood as wisdom of the crowd or a rule-book which sets out the industry knowledge how to perform successfully on the global market (Monaghan - Tippmann 2018).

As the studies listed above relate mostly to the advanced economies it would be interesting to examine competitive strategies followed by the firms from emerging markets. It might be expected that with much more limited resources rapid internationalisation would be possible only if the strategy pursued assumes 
targeting a niche segment with a standardised product. Only after successful expansion they could be able to collect resources necessary for product or service differentiation. However, according to the 'stages' model gradually expanding firms might already have the necessary resources and experience collected to create distinctive offering thus allowing them for pursuing a differentiation strategy. Thus, the first research question refers to differences/similarities between competitive strategies of rapidly and incrementally internationalising firms.

\subsection{Product innovations}

There is a common agreement in the literature that product innovativeness is a core element of the competitive strategies followed by rapidly internationalising firms. This is because those companies tend to focus on high-tech industries which require cutting-edge technology, superior quality and unique product design, being at the same time less culture dependent and requiring small adjustments to meet local customer needs (Chetty - Campbell-Hunt 2004; Elenurm 2007; Andersson et al. 2014; Rialp et al. 2015; Cavusgil - Knight 2015). Furthermore, the need to amortise high R\&D costs imposes a quick expansion across borders (Andersson et al. 2014). As many young and small firms may not be financially and organisationally capable of conducting R\&D research by themselves, it might be necessary for them to find and turn to strategic partners with a leading market position in science, technology or design (Elenurm 2007; Cavusgil - Knight 2015). In the case of Polish international new ventures it was also found that the strategy to create and bring into the market high-quality, innovative and differentiated products is strongly linked with the perception of the financial success (Sikora Baranowska-Prokop 2018).

On the other hand, Rialp et al. (2015) argue that incrementally internationalising companies are not required to be as innovative as the rapidly expanding firms. Therefore their capability to create value added offering might be limited. This reasoning was confirmed in the study conducted by Kowalik et al. (2017), which pointed out that a much higher portion of rapidly internationalising firms introduced innovations in form of new products and production technologies than gradually internationalising companies.

It would be interesting then to examine the gradually and rapidly internationalising firms from emerging markets to find out what their approaches towards product innovativeness are. 


\subsection{Marketing}

Firms following rapid internationalisation are usually associated with differentiated marketing, ability to adapt to changing conditions in foreign markets, strong market orientation and a clear marketing strategy embracing branding, marketing competences, intellectual property protection, and customer feedback monitoring (Roth - Morrison 1992; Chetty - Campbell-Hunt 2004; Cavusgil - Knight 2015). Additionally, focus on bringing a new, innovative product and taking a position in a global market niche gives the Born Global companies an opportunity to set the price for their products more freely (Neubert 2017). However, firms going abroad in incremental steps prefer to exert a more direct control over marketing and distribution activities in foreign markets (Chetty - Campbell-Hunt 2004). Therefore they may be more likely to follow traditional patterns of international expansion focused on risk management and cost reduction. It might be interesting to observe whether firms from emerging markets show the same preferences in the light of limited resources as firms from developed markets. In particular it might be expected that regardless of the internationalisation path the companies from emerging markets should prefer more conservative behaviour, i.e. only the solutions with a proven track record would be accepted. Only then would they be able to mitigate excessive business risks.

\subsection{Entrepreneurial orientation}

There are no conclusive research results regarding global orientation of managers with reference to the model of internationalisation of their firms. Some authors argue that basically there are no significant differences between rapidly and incrementally internationalising firms. However, Moen - Servais (2002) noticed that managers from INVs demonstrated more globally oriented vision, proactiveness and responsiveness. By contrast, other scholars reasoned that born globals' entrepreneurs were more likely than others to seize the opportunities in foreign markets (Rialp et al. 2005). The same finding comes from the study conducted by Kowalik et al. (2017), whereby Polish managers in rapidly internationalising firms were more prone to take business risks than their counterparts in incrementally expanding companies, which refers to higher proactiveness. It might be interesting then to move that study further and investigate what the views and entrepreneurial orientation of emerging market managers in terms of their vision and responsiveness are.

It is pointed out by some scholars that the traditional companies are not interested at all in internationalisation. According to the 'stages' model of inter- 
nationalisation those companies were not required to differentiate. By contrast, international orientation and niche market focus is central for the rapidly internationalising firms as otherwise they would not be able to develop necessary competitive advantages (Chetty - Campbell-Hunt 2004). Therefore our next research question relates to motivations behind internationalisation to understand better how firms entering foreign markets (gradually and rapidly) formulate their competitive strategy and what role it plays for them.

\subsection{Flexibility}

One of the major factors determining competitive advantage of a company is the ability to adapt to changing and new business environments in a flexible manner (Elenurm 2007). In reference to foreign markets, higher flexibility in adapting to changing conditions and stronger customer orientation is demonstrated rapidly by comparison to gradually expanding firms (Rialp et al. 2005). It is argued that the latter group of firms first pursue international strategies which require only limited flexibility. These companies might have developed routines in the domestic market which deter them from knowledge assimilation. As a result they are more likely to overlook opportunities in foreign markets. It is the reason why rapidly internationalising firms should be more flexible and innovative as they could use the so called first-mover advantages in foreign markets before other firms do (McNaughton 2003). Accordingly, one of our objectives in this research is to examine both groups of the firms going abroad through the lenses of organisational flexibility. We would like to find out whether the rapidly internationalising firms are more agile in spotting and taking business opportunities in foreign markets.

\subsection{Network relationships}

It is a common view that rapidly internationalising firms create and extensively use business networks. These networks are developed much more rapidly and on a broader scope compared to firms expanding gradually (Chetty - CampbellHunt 2004; Rialp et al. 2005). They are built with different kinds of stakeholders including distributors, agents, representatives, and suppliers. The networking capability is used to identify attractive niche markets, develop products dedicated for those markets and to improve overall performance of international expansion (Cavusgil - Knight 2015). It is also stressed that networks provide knowledge, management's social and industry relationships, reduce risk and thus may facilitate faster internationalisation by reducing the limitations created by scarce 
and lacking resources. Otherwise it could take them years to build the resources required to expand into foreign markets (Gulanowski et al. 2018).

Interestingly, the gradually expanding firms use the networks in the same manner, however the only difference is scope and speed in which the networks are developed (Chetty - Campbell-Hunt 2004). It is stressed, however, that in mature industries where the networks are already developed it might be very difficult for INVs or "Born Globals" to expand and compete successfully. In such industries firms going abroad in incremental steps would be more likely to succeed. However, it would require a conservative approach with low risk export entry modes and entering geographically close markets (Andersson et al. 2014).

Our last research question relates to how rapidly and incrementally internationalising firms approach development of their business networks in foreign markets and how they differ in that area from their counterparts located in developed economies.

\section{METHOD}

In this study data from two separate research studies were used: one focusing on rapidly internationalising firms performed in 2017, the other on incrementally internationalising firms done in early 2018. In both studies data was collected in semi-structured individual in-depth interviews with company founders or higher rank managers (like e.g. Executive Board members) that lasted more than one hour (not exceeding two hours in any of the cases). Data collected in interviews were supplemented by secondary data available so that several case studies were created. Cross-case analysis was applied.

Case study approach was undertaken to better understand the processes going on in studied organizations and as it was the most suitable method to answer the research questions formulated in this study (Yin 2009). This study aims at better understanding of strategic decisions undertaken in studied firms thus qualitative research is the best approach to identify, analyse and compare research constructs (Hair et al. 2007; Baxter - Jack 2008). The particular case selection was deliberate as in this methodological approach studied companies should represent cases where the theoretical interest would be more evident than in others. The number of cases should vary from 4 to 12 as such number of cases is sufficient to notice changes in the phenomenon and achieve deeper insights (Eisenhardt 1989) so we decided to have twelve cases in total (six cases of each type).

Nonprobability sampling was applied in both original research studies. All the firms were of Polish origin and fully owned by Polish entrepreneurs. Rapidly internationalising firms had to meet the following criteria: 
1. Production SMEs with their registered seat in Poland established in the period 2006-2016;

2. Enterprises with predominantly Polish capital during the whole period of the companies' operations i.e. from the moment of their formal registration to the moment of the research;

3. Independent enterprises, i.e. those that do not belong to any capital group, unless they form such a group as a mother company themselves;

4. The founder of the company can only be an individual entrepreneur (or several individual entrepreneurs);

5. Enterprises that have achieved 25 per cent of revenues from foreign operations no later than in their third year of operations ${ }^{2}$.

The incrementally internationalising firms had to meet the following criteria:

1. Production enterprises with their registered seat in Poland being at least 5 years old;

2. Enterprises with predominantly Polish capital during the whole period of the companies' operations i.e. from the moment of their formal registration to the moment of the research;

3. Enterprises that started their internationalisation not earlier than in their fourth year of operations.

The interviews' script in both research studies was different but parts of the script overlapped, which allowed for comparisons applied in this study. Table 2 presents basic characteristics of the studied firms.

\section{ANALYSIS AND RESULTS}

Several dimensions of competitive strategies discussed in the above literature review were analysed on the basis of 12 case studies.

\subsection{Type of competitive strategy (market focus and scope)}

There is no clear pattern as far as strategies of analysed rapid and incremental internationalisers are concerned (Table 3). In both groups there are firms focusing on broad and narrow market. Some firms, like company D 2018 operate on both types of markets: "We have several product categories and in some we operate in

2 We are aware that there exist other definitions of rapidly internationalising firms, however, we decided to apply the one that is used most often. 


\begin{tabular}{|c|c|c|c|c|c|c|c|c|c|c|}
\hline $\begin{array}{c}\text { (pro.xqe) } \\
\text { әшоч sәəКо|dü }\end{array}$ & $\hat{e}$ & ê & $\begin{array}{l}0 \\
0 \\
b\end{array}$ & $\begin{array}{l}e \\
\text { in }\end{array}$ & $\underset{\infty}{\infty}$ & $\begin{array}{l}0 \\
0 \\
0\end{array}$ & $\begin{array}{l}0 \\
0 \\
i n\end{array}$ & $\begin{array}{l}\hat{\delta} \\
\stackrel{e}{0} \\
0 \\
\vdots \\
i\end{array}$ & 产 & 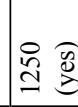 \\
\hline \% ‘SLSH & 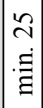 & 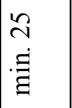 & 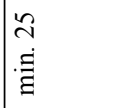 & $\begin{array}{l}\approx \\
i \\
\dot{a}\end{array} \mid$ & 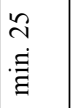 & 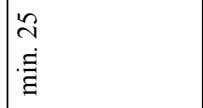 & $\infty$ & 8 & 안 & 吾 \\
\hline 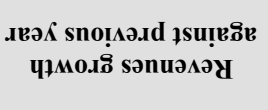 & 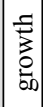 & 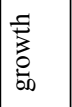 & $\stackrel{\circ}{\circ}$ & 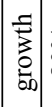 & $\grave{\infty}_{\infty}^{\circ}$ & 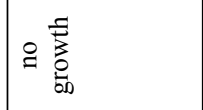 & 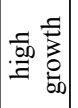 & ळें & $\therefore$ & $\stackrel{\circ}{\circ}$ \\
\hline 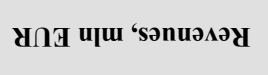 & $\stackrel{\circ}{\vec{v}}$ & $\stackrel{0}{0}$ & $\stackrel{0}{0}$ & $\frac{7}{0}$ & i. & $\stackrel{\Delta}{0}$ & i & $\because$ & $\stackrel{2}{\approx}$ & $\stackrel{\text { I }}{ }$ \\
\hline 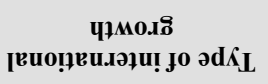 & : & : 픔 & 를 & : & 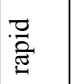 & : & $\begin{array}{l}\mathscr{8} \\
\frac{\pi}{\infty}\end{array}$ & $\begin{array}{l}\mathscr{D}_{0} \\
\frac{\pi}{\omega}\end{array}$ & $\begin{array}{l}\mathscr{E} \\
\frac{\pi}{5} \\
\frac{\pi}{n}\end{array}$ & 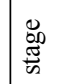 \\
\hline 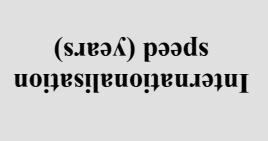 & 0 & $a$ & - & $N$ & $m$ & - & $=$ & $\theta$ & n & 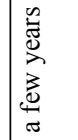 \\
\hline 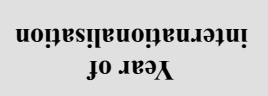 & 足 & $\overline{\vec{i}}$ & $\stackrel{n}{\stackrel{n}{n}}$ & $\mid \begin{array}{l}0 \\
\stackrel{N}{N}\end{array}$ & $\stackrel{n}{\stackrel{n}{c}}$ & $\overline{\vec{i}}$ & $\underset{d}{\stackrel{d}{0}}$ & ষ্ণ & $\hat{a}$ & $\stackrel{\oplus}{\ddot{g}}$ \\
\hline ұиәшц & 齐 & ஓे & 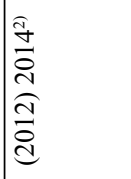 & $\vec{d}$ & $\stackrel{\sim}{\stackrel{N}{\sim}}$ & $\stackrel{\circ}{\stackrel{1}{\sim}}$ & $\hat{\sigma}$ & 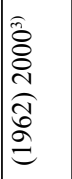 & 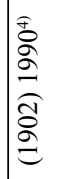 & $\widehat{\Omega}$ \\
\hline K.ısnpuI & 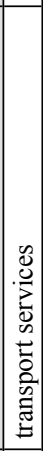 & 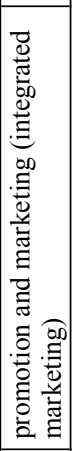 & 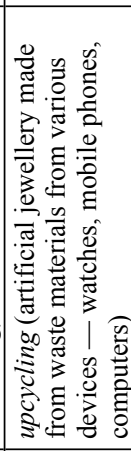 & 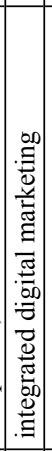 & 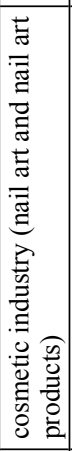 & 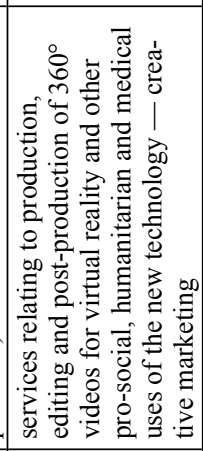 & 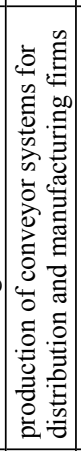 & 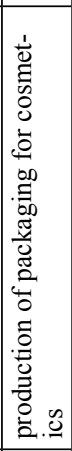 & 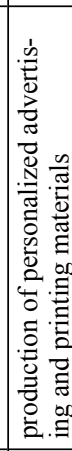 & 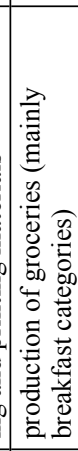 \\
\hline доңэәs ग!шочоэ & \begin{tabular}{|l|}
0 \\
0 \\
0 \\
0 \\
0 \\
0 \\
0
\end{tabular} & 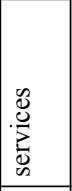 & 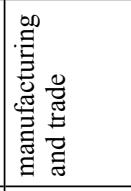 & 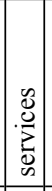 & 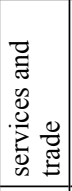 & 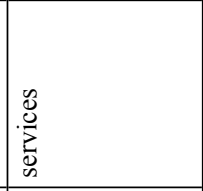 & 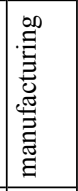 & 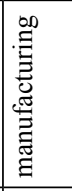 & 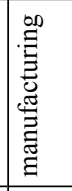 & 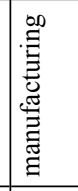 \\
\hline (ㄴ․! & 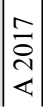 & $\begin{array}{l}\tilde{D} \\
\stackrel{\sim}{\sim} \\
\infty\end{array}$ & 골 & 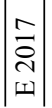 & 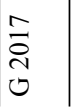 & 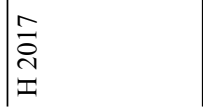 & 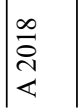 & $\begin{array}{l}\infty \\
\stackrel{\sim}{*} \\
\sim \\
\infty\end{array}$ & 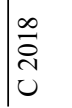 & 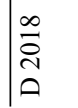 \\
\hline
\end{tabular}




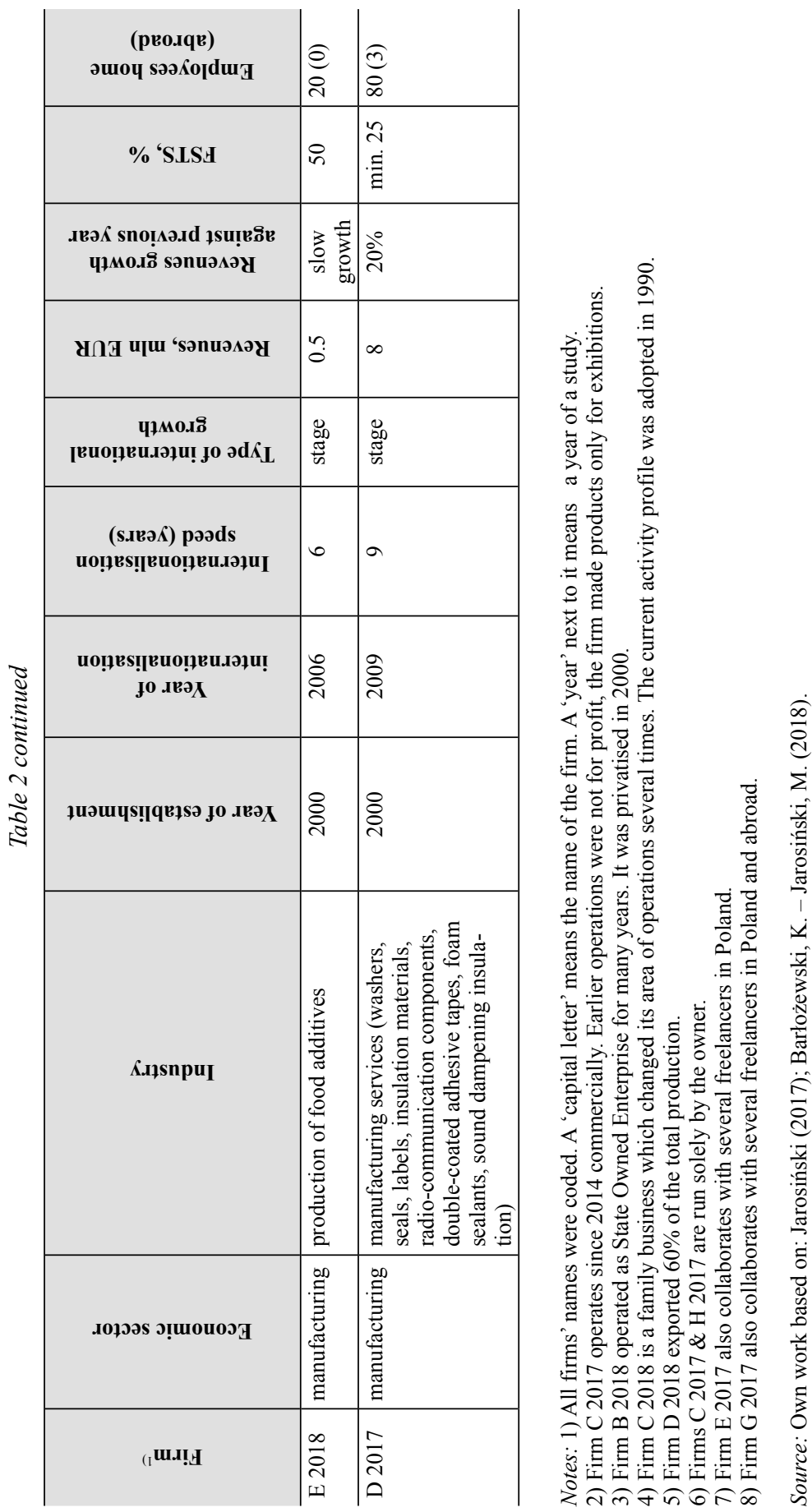


Table 3. Strategies' characteristics of the studied firms

\begin{tabular}{|l|l|l|l|l|l|l|l|}
\hline $\begin{array}{l}\text { Firm } \\
\text { code }\end{array}$ & $\begin{array}{l}\text { Market } \\
\text { scope }\end{array}$ & Customers & $\begin{array}{l}\text { Customers' } \\
\text { size }\end{array}$ & $\begin{array}{l}\text { Competitive } \\
\text { strategy }\end{array}$ & $\begin{array}{l}\text { Strategy } \\
\text { moves' } \\
\text { character }\end{array}$ & $\begin{array}{l}\text { Product } \\
\text { innovativeness }\end{array}$ & $\begin{array}{l}\text { Product } \\
\text { technological } \\
\text { advancement }\end{array}$ \\
\hline A 2017 & broad & mass & varied & best-cost provider & calm & medium & medium \\
\hline B 2017 & broad & individual & varied & differentiation & calm & high & high \\
\hline C 2017 & narrow & individual & small & differentiation & calm & high & low \\
\hline E 2017 & broad & mass & varied & differentiation & calm & low & medium \\
\hline G 2017 & narrow & individual & small & best-cost provider & aggressive & high & high \\
\hline H 2017 & narrow & individual & varied & differentiation & calm & high & high \\
\hline A 2018 & narrow & individual & large & best-cost provider & calm & medium & medium \\
\hline B 2018 & narrow & individual & large & differentiation & calm & low & medium \\
\hline C 2018 & broad & individual & large & differentiation & calm & low & low \\
\hline D 2018 & broad & mass & varied & differentiation & aggressive & high & low \\
\hline E 2018 & narrow & individual & varied & best-cost provider & calm & low & low \\
\hline D 2017 & narrow & individual & large & differentiation & aggressive & high & high \\
\hline
\end{tabular}

Source: See Table 1.

a niche, because Bio Organic for example is a niche. But on a broad market we are present with basic products."

If firms choose narrow market to operate on they address their offer to single customers (either large or small). In case of a broad market target the target customers may be mass customers or single customers depending on the business. Again the size of customers may vary. Speaking about the character of competitive moves on the markets calm strategy dominates in both groups of firms. For example, the manager from company A 2018 said "We know that we are very competitive, so we do not have to use any aggressive strategy here".

The common feature of all studied firms is that they compete using the quality advantage and as a result some of them apply differentiation strategy. For example, the founder of company G 2017 said "We are not cheap but price doesn't matter. Quality matters". The owner of company D 2017 indicated "This is a different level (very high) of quality expectations. For many people it's totally illogical but we are already living in this world, we have got used to it".

Some of the firms (regardless of the type ${ }^{3}$ ) compete at the same time with cost advantage thus using best-cost-provider strategy. According to the manager from company A 2018: "The costs are lower if we are talking about foreign markets ... lower price than the competition, while going alongside with the quality of these products".

By 'firm type' authors mean the differentiation of firms in terms of internationalisation's pace (rapid or incremental). 


\subsection{Product innovations}

As far as product innovativeness and product technological advancement are concerned rapid internationalisers tend to have it at a rather high or at least medium level (Table 3). The founder of company H 2017 said: "the innovation that I make is on a global scale, you can say because it is noticeable all over the world and thanks to it I made contacts with decision-makers in a big technological corporation".

In the case of firms internationalising incrementally this is not that obvious. Two studied firms have highly innovative products but only in one of these two cases is product technological advancement high. The founder of company D 2017 noticed "We have several dozens of products. We have products that are very poorly innovative but we also have the 'top' ones. We have both of them".

\subsection{Marketing}

All rapidly internationalising firms in the sample develop their products at home while incrementally internationalising firms also develop their products at home but for two firms that also manufacture products developed by their customers (Table 4). What all incremental internationalisers have in common with rapid internationalisers in the sample is product customisation to foreign markets/customers. The export manager of company D 2018 explained "We base on what is made in our technology and adapt it to the requirements ... Well, you have to think, if they do it, do they really need products we give them, or a little bit modified? ... And now you have to see what they eat and adapt to it and meet their expectations".

As far as distribution is concerned three rapidly internationalising firms deliver their products on-line due to their character of operations. Two other firms deliver their products directly to customers. All incrementally internationalising firms deliver their products directly to customers but for one firm who combined direct mass distribution to points of sales with indirect one via contracted distributors.

Rapidly internationalising firms in the sample seem to be more active in their marketing activities. Most of them use different marketing media concentrating a lot on Internet channels. The founder of firm A 2017 revealed "Here there are a lot of different types of advertising from Google AdWords through website positioning, via OLX, advertising on Facebook, in social media". An important way to gain new customers for most of the firms was also a recommendation of another customer. This was e.g. the case of firm B 2017: "when it comes to advertising, as I said, we rely mainly on recommendations". All marketing actions 
Table 4. Marketing dimension of the studied firms

\begin{tabular}{|c|c|c|c|c|c|c|}
\hline 声 & 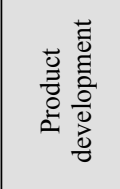 & 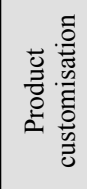 & 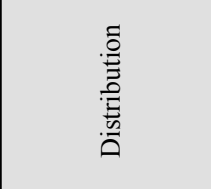 & 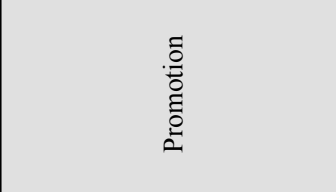 & 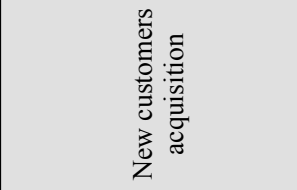 & 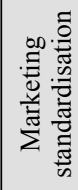 \\
\hline A 2017 & at home & yes & $\begin{array}{l}\text { directly to } \\
\text { customer }\end{array}$ & $\begin{array}{l}\text { Internet (e.g. Google Ad- } \\
\text { Words, website positioning), } \\
\text { Facebook and other social } \\
\text { media, mailing to potential } \\
\text { customers. } \\
\text { Only in Poland: trade maga- } \\
\text { zines, flyers, a few banners }\end{array}$ & $\begin{array}{l}\text { mainly through } \\
\text { advertising and word-of- } \\
\text { mouth }\end{array}$ & no \\
\hline B 2017 & at home & yes & on-line & $\begin{array}{l}\text { personal branding tools, } \\
\text { social media, internet }\end{array}$ & $\begin{array}{l}\text { mainly through word-of- } \\
\text { mouth and as a result of } \\
\text { training courses }\end{array}$ & no \\
\hline C 2017 & at home & yes & $\begin{array}{l}\text { directly to } \\
\text { customer via } \\
\text { couriers }\end{array}$ & $\begin{array}{l}\text { Facebook, Instagram, small } \\
\text { promotional events on a } \\
\text { dedicated portal }\end{array}$ & $\begin{array}{l}\text { mainly through word-of- } \\
\text { mouth }\end{array}$ & no \\
\hline Е 2017 & at home & yes & on-line & $\begin{array}{l}\text { Internet (AdWords cam- } \\
\text { paigns) }\end{array}$ & $\begin{array}{l}\text { through AdWords cam- } \\
\text { paigns and networking }\end{array}$ & no \\
\hline G 2017 & at home & yes & $\begin{array}{l}\text { during the train- } \\
\text { ing (distribution } \\
\text { of nail stylisation } \\
\text { products) }\end{array}$ & $\begin{array}{l}\text { trade magazines, Facebook } \\
\text { and other social media }\end{array}$ & $\begin{array}{l}\text { through Facebook and } \\
\text { trainers conducting the } \\
\text { courses }\end{array}$ & no \\
\hline Н 2017 & at home & yes & on-line & $\begin{array}{l}\text { infrequent advertising } \\
\text { campaigns }\end{array}$ & through Internet & no \\
\hline A 2018 & at home & yes & assembly on site & mainly word-of-mouth & $\begin{array}{l}\text { mainly through word-of- } \\
\text { mouth }\end{array}$ & yes \\
\hline B 2018 & at home & yes & $\begin{array}{l}\text { directly to } \\
\text { customer }\end{array}$ & $\begin{array}{l}\text { trade fairs and direct } \\
\text { marketing }\end{array}$ & $\begin{array}{l}\text { trade fairs and direct } \\
\text { contacts }\end{array}$ & no \\
\hline C 2018 & $\begin{array}{l}\text { by a } \\
\text { customer }\end{array}$ & yes & $\begin{array}{l}\text { directly to } \\
\text { customer }\end{array}$ & trade fairs & $\begin{array}{l}\text { through Presents Interna- } \\
\text { tional Institute; gener- } \\
\text { ally passive approach to } \\
\text { customer acquisition }\end{array}$ & no \\
\hline D 2018 & at home & yes & $\begin{array}{l}\text { mass distribution } \\
\text { directly to POS } \\
\text { or via a contract- } \\
\text { ed distributor } \\
\end{array}$ & mass marketing & $\begin{array}{l}\text { active approach to } \\
\text { customer acquisition }\end{array}$ & no \\
\hline E 2018 & at home & yes & $\begin{array}{l}\text { directly to } \\
\text { customer or via } \\
\text { a contracted } \\
\text { distributor } \\
\end{array}$ & mainly word-of-mouth & through distributors & no \\
\hline D 2017 & $\begin{array}{l}\text { by a } \\
\text { customer }\end{array}$ & yes & $\begin{array}{l}\text { directly to } \\
\text { customer via } \\
\text { couriers }\end{array}$ & word-of-mouth & $\begin{array}{l}\text { mainly through word-of- } \\
\text { mouth }\end{array}$ & n.a. \\
\hline
\end{tabular}

Source: See Table 1. 
are customised. Incrementally internationalising firms in the sample seem more conservative. Some of them promote themselves at trade fairs ("We went to this trade fair every year for 15 years" - company C 2018) and rely a lot on recommendations of their customers. Only two firms were more active in gaining new customers. None of the firms but for one standardise marketing actions.

\subsection{Entrepreneurial orientation}

As for rapidly internationalising firms only two out of the six studied firms from the very beginning intended to internationalise their activities (Table 5). In the case of the other four the idea emerged later but in one of the firms the idea to internationalise emerged shortly after the start of operations. In each of these companies the willingness to internationalise was awoken by a different factor: an order from a client abroad, a natural consequence of growth, an impulse produced by a certain fact, the lack of interesting offers on the domestic market combined with a preference to work on-line rather than have a direct contact with clients. The founder of company D 2017 explained "A remote market, which seemed to enable me to interact with people through a computer window, gave me much more security and comfort at work ... And when it comes to international activities, it is primarily a foreign currency that attracted me".

In the case of three businesses, the first contact with a foreign client was initiated by the company founder, whereas in the other three the initiative was first displayed by foreign customers.

As for incrementally internationalising firms in four out of the six studied firms the idea to internationalise came later. It is interesting that in the case of two firms the idea was present from the beginning. In one of the firms the owner indicated that he wanted to prepare the firm for international competition before entering international markets (D 2017): "We knew from the beginning and observed globalisation. We knew that we would start from the Polish market, because it is the easiest to communicate here, the same culture, etc. We know the requirements of clients ... At some point, bigger and bigger clients appeared, who were part of international corporations". In the other case the owner did not explain why he had delayed internationalisation despite having this idea from the beginning.

In each of these companies the willingness to internationalise was awoken by a different factor, however, some of the motives were similar to the ones of rapid internationalisers from the sample: an order from a foreign customer (two firms), limitations to growth on the domestic market (two firms), a natural consequence of growth (to achieve economies of scale in production and increase revenues) and firm's restructuring. In the case of four firms foreign customers were ac- 







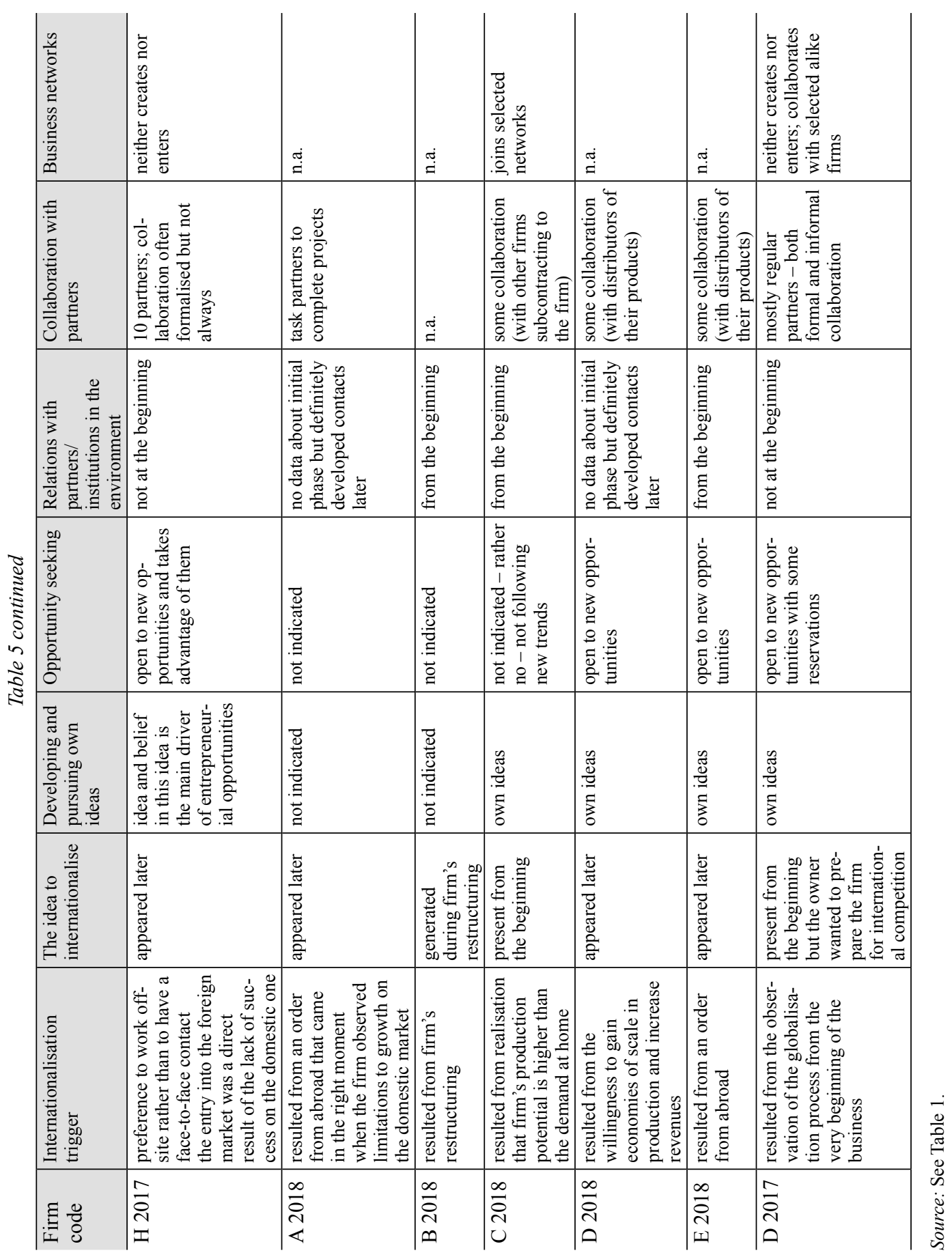


tively sought by entrepreneurs as in company B 2018: "That was the assumption. I mean, at the beginning it was necessary to invest in infrastructure, because the buildings were in very poor condition, the machinery was poor, so those early years were just an investment in the company and then looking for contractors".

Speaking about relation between entrepreneurial orientation and competitive strategies all the studied rapid internationalisers were seeking to achieve the above average quality to be competitive on foreign markets which resulted in differentiation or best-cost provider strategy because from the moment they had decided to internationalise they had known that this would be the only way to gain a share in foreign markets. In the case of incremental internationalisers the reasons to choose differentiation or best-cost provider strategy were similar, however, some of them were also seeking to be price competitive.

\subsection{Flexibility}

Speaking about the agility in spotting and taking business opportunities in foreign markets we can say that four out of six entrepreneurs running rapidly internationalised firms in the study pursue their own ideas (Table 5). The other entrepreneurs did not mention that during the interviews but following the development of their firms we think that they also must be doing that. Definitely all of them are open to new opportunities and take advantage of them. However, some interview participants let the impulse guide them, while others rely on their intuition. The co-founder of company B 2017 said: "I always teach at all workshops, trainings, lectures that business should be thought out with a business plan, but I often make very spontaneous decisions myself, i.e. we see a business opportunity and try to capture it. We do not necessarily prepare for it somehow, because I know that if we start the preparation process, the opportunity may disappear. We use the opportunity and often react to market trends trying to introduce some new product or service".

As for incrementally internationalising firms it seems that four out of six firms also develop and follow their own ideas and some of them are also open to new opportunities. Definitely one of the owners is, however, resistant to following new trends in the market. He said: "New techniques are coming in and we are a bit left behind with old techniques, it's just digitalisation of print. We only use traditional print" (company C 2018).

In two cases, the interviewees did not share any information on this matter. 


\subsection{Network relationships}

Five out of six rapidly internationalising firms used their networks from the very beginning of internationalisation (Table 5). The firm which did not use networks at the start developed contacts with partners over time. The founder of company E 2017 explained: "We did not build a network of contacts before, this was not our goal. We tried to establish well on the Polish market ... we know how to do it now. The network of contacts develops based on the fact that we know that we can and we know how, that there is no problem and that each of us has competences ... (now) you are in a place where you meet people who have similar needs or looking at the market. And you just exchange business cards, say what you do and keep in touch ... And they say: I remember you from this event, do you still deal with this and this, if so, we are just entering the Polish market. And can you send an offer because we have such a need".

The number of partners' varies among the six studied firms. As for new networks now two firms do not either create them or enter them. Four other firms declare that they enter new networks and three of them even create new ones.

As for incrementally internationalising firms three out of six firms used their networks from the very beginning of internationalisation. One firm definitely did not. As for two other firms this information was not available. All the firms developed contacts over time and today they collaborate with partners. As the manager from company B 2018 explained "It is important for us to establish such long-term relationships". As for new networks now two firms definitely engage in the existing ones but do not create any new networks. For four other firms this information is not available.

\section{CONCLUSION}

Having done cross-case analysis we have achieved many interesting findings which were summarized according to our research questions (Table 6).

Although some scholars (Griffith et al. 2008; Śliwiński 2012; Trąpczyński 2013; Cavusgil - Knight 2015) stressed the necessity to investigate differences between gradually and rapidly internationalising companies, our research did not unveil significant changes in the competitive strategies applied by both groups. It was expected that the rapidly internationalising firms should focus more intensively than traditional companies on technological innovations, agility, creating business networks and expanding in a niche market on a global scale (Chetty - Campbell-Hunt 2004; Rialp et al. 2005). It was presumed that differences in external and internal environments of those firms will lead to different strategies 
Table 6. Research questions and basic findings

\begin{tabular}{|c|c|}
\hline Research questions & Basic findings \\
\hline $\begin{array}{l}\text { 1. What are the differences/similari- } \\
\text { ties between competitive strategies } \\
\text { of rapidly and incrementally } \\
\text { internationalising firms in emerging } \\
\text { markets? }\end{array}$ & $\begin{array}{l}\text { There is no clear pattern but the common feature of } \\
\text { all studied firms is that they compete using the quality } \\
\text { advantage and as a result some of them apply differentia- } \\
\text { tion strategy. Some of the firms (regardless of the type) } \\
\text { compete at the same time with cost advantage using best- } \\
\text { cost-provider strategy. }\end{array}$ \\
\hline $\begin{array}{l}\text { 2. What are the approaches } \\
\text { of gradually and rapidly } \\
\text { internationalising firms from } \\
\text { emerging markets towards product } \\
\text { innovativeness? }\end{array}$ & $\begin{array}{l}\text { Rapid internationalisers tend to have product innova- } \\
\text { tiveness at a rather high or at least medium level. Firms } \\
\text { internationalising incrementally have product innovative- } \\
\text { ness at lower level but for two cases. }\end{array}$ \\
\hline $\begin{array}{l}\text { 3. What are the approaches of } \\
\text { rapidly and gradually internationalis- } \\
\text { ing firms from emerging markets } \\
\text { towards marketing? }\end{array}$ & $\begin{array}{l}\text { All firms in the sample, irrespective of type, customize } \\
\text { their products to foreign markets/customers and almost } \\
\text { all deliver their products directly to customers. } \\
\text { Rapidly internationalising firms in the sample tend to be } \\
\text { more active in their marketing activities. Most of them } \\
\text { use different marketing media concentrating a lot on } \\
\text { Internet channels. Incrementally internationalising firms } \\
\text { in the sample seem more conservative. }\end{array}$ \\
\hline $\begin{array}{l}\text { 4. What are the motives behind } \\
\text { internationalisation of rapidly and } \\
\text { gradually internationalising firms } \\
\text { from emerging markets and how } \\
\text { they are related to their competitive } \\
\text { strategies? }\end{array}$ & $\begin{array}{l}\text { In each of the companies in the sample the willingness } \\
\text { to internationalise was awoken by a different factor, } \\
\text { however, some of the general motives to internationalise } \\
\text { were similar in both groups of firms. Two firms from } \\
\text { each type developed the idea to internationalise from the } \\
\text { very beginning. } \\
\text { From the moment the rapid internationalisers decided } \\
\text { to internationalise they knew that achieving the above } \\
\text { average quality would be the only way to gain a share in } \\
\text { foreign markets. In the case of incremental internation- } \\
\text { alisers the reasons to choose differentiation or best-cost } \\
\text { provider strategy were similar, however, some of them } \\
\text { were also seeking to be price competitive. }\end{array}$ \\
\hline $\begin{array}{l}\text { 5. Are rapidly or gradually inter- } \\
\text { nationalising firms from emerging } \\
\text { markets more agile in spotting and } \\
\text { taking business opportunities in } \\
\text { foreign markets? }\end{array}$ & $\begin{array}{l}\text { All the studied firms developed and successfully fol- } \\
\text { lowed their own ideas and were looking for business } \\
\text { opportunities on international markets. One of the owners } \\
\text { of incrementally developing firms was resistant to fol- } \\
\text { lowing new trends in the market. }\end{array}$ \\
\hline $\begin{array}{l}\text { 6. How rapidly and incrementally } \\
\text { internationalising firms approach } \\
\text { development of their business } \\
\text { networks in foreign markets and how } \\
\text { do they differ in that area from their } \\
\text { counterparts located in developed } \\
\text { economies? }\end{array}$ & $\begin{array}{l}\text { All the firms developed business contacts over time and } \\
\text { collaborated with new partners. Most of } \\
\text { rapidly internationalising firms used their networks from } \\
\text { the very beginning of internationalisation. As for incre- } \\
\text { mentally internationalising firms three out of six firms } \\
\text { used their networks from the very beginning of interna- } \\
\text { tionalisation and one firm definitely did not. }\end{array}$ \\
\hline
\end{tabular}


and processes (Hoppner - Griffith 2015). Other authors shared a different view and they argued that there are no evident reasons why the strategies adopted by rapidly and gradually expanding firms should compete differently (Harveston 2000; Moen - Servais 2002; Kowalik et al. 2017).

Moen, who investigated differences between born global firms and other exporters, concentrated on export strategies, competitive advantage and international orientation. He concluded that there are no significant differences between born global firms operating for several years on foreign markets and global firms that have been in existence for several decades (Moen 2002).

Indeed, our study provides more reasons to reckon that the gradually expanding firms apply similar strategies and in fact both groups seem to be more likely to apply differentiation rather than cost-effective strategy. It must be noted that some entities are using best-cost-provider strategy regardless of their type, i.e. gradually or rapidly internationalising. Based on our results one may reason that the speed of internationalisation does not impact significantly the competitive positions the analysed companies seek to acquire. These aspects would then be similar to earlier studies.

The two types of firms still may differ in terms of tangible and intangible resources, knowledge and experience gathered on foreign markets, possibilities to gain economies of scale and others but both groups seem to configure and use those factors in the manner which allows them for taking the most attractive market position.

All studied firms compete in their markets using the quality advantage in some cases (in both groups of firms) supplemented by the cost advantage. At the same time most firms describe their strategy moves as rather calm. Besides this, all firms in the sample customise their products to foreign markets/customers. Some of the motives to internationalise were similar in both groups of firms and thirdly looking for business opportunities on international markets all the studied firms also developed and successfully followed their own ideas. Following their internationalisation paths they developed business contacts over time and collaborated with new partners.

An interesting observation, which can also be treated as a similarity to some extent, is that among incrementally internationalising firms there were two firms whose founders had an idea to internationalise already at the inception of these firms. This is the feature, by definition, attributed to rapidly internationalising firms. However in the case of the studied six rapidly internationalised firms only two of them were created already with the idea to internationalise and one developed this idea soon after beginning its operations.

As for the differences between rapidly and incrementally internationalising firms we can see that definitely rapid internationalisers tend to have product in- 
novativeness and product technological advancement at higher levels than incremental internationalisers. Rapidly internationalising firms are also more active in their marketing activities. This is in line with observations that although "Polish INVs conform in many respects to previously observed patterns, early internationalization which they display also has certain specific features" (Nowiński Rialp 2013: 221).

Our research has some limitations. First, our study is based on a limited sample of Polish firms. Therefore it is not possible to generalise our results to firms from other emerging markets. Second, we only gathered and analysed a very limited scope of information regarding the firms' competitive strategies and their internationalisation processes. Thus we did not capture a broad span of other factors, e.g. networking capabilities, business process organisation, and technology-related factors, which we could find important to develop competitive advantages. They might determine competitive advantages of firms and as a result play a significant role in crafting competitive strategies in international markets. We believe these factors should be tested in a future research which should also be extended to a larger number of firms and more countries.

\section{REFERENCES}

Andersson, S. - Evers, N. - Kuivalainen, O. (2014): International New Ventures: Rapid Internationalization across Different Industry Contexts. European Business Review, 26(5): 390-405.

Baranowska-Prokop, E. - Sikora, T. (2015): Competitive Strategy versus Sector-Specific Determinants in Success Perception of Polish Born Globals. Journal of International Studies, (8)1: 9-21.

Barłożewski, K. - Jarosiński, M. (2017): Zmiany strategii działania polskich przedsiębiorstw na rynku międzynarodowym w różnych okresach ekspansji zagranicznej (Changes in the Strategy of Polish Firms Operating on International Market in Different Periods of Foreign Expansion). Research Report, SGH Warsaw School of Economics, Warsaw.

Baxter, P. - Jack, S. (2008): Qualitative Case Study Methodology: Study Design and Implementation for Novice Researchers. The Qualitative Report, No. 13(4), Nova Southeastern University.

Bouncken, R. B. - Muench, M. - Kraus, S. (2015): Born Globals: Investigating the Influence of Their Business Models on Rapid Internationalization. International Business \& Economics Research Journal, 14(2): 247-255.

Campbell-Hunt, C. (2000): What have We Learned about Generic Competitive Strategy? A MetaAnalysis. Strategic Management Journal, 21(2):127-154.

Cavusgil, S. T. - Knight, G. (2015): The Born Global Firm: An Entrepreneurial and Capabilities Perspective on Early and Rapid Internationalization. Journal of International Business Studies, 46: 3-16.

Chetty, S. - Campbell-Hunt, C. (2004): A Strategic Approach to Internationalization: A Traditional versus a "Born-Global" Approach. Journal of International Marketing, 12(1): 57-81.

Eisenhardt, K. M. (1989): Building Theories from Case Study Research. Academy of Management Review, 14 (4): 532-550. 
Elenurm, T. (2007): International Competitiveness and Organizational Change Drivers Anticipated by Estonian Managers in the Context of European Integration. Baltic Journal of Management, 2(3): 305-318.

Gorynia, M. (2004): Competitiveness of Polish Firms and the European Union Enlargement, Competitiveness Review. An International Business Journal, 14(1-2): 1-11.

Griffith, D. A. - Cavusgil, S. T. - Xu, S. (2008): Emerging Themes in International Business Research. Journal of International Business Studies, 39: 1220-1235.

Gulanowski, D. - Papadopoulos, N. - Plante, L. (2018): The Role of Knowledge in International Expansion. Toward an Integration of Competing Models of Internationalization. Review of International Business and Strategy, 28(1): 35-60.

Hair, J. F. - Money, A. H. - Samouel, P. - Page, M. (2007): Research Methods for Business. West Sussex: John Wiley \& Son Ltd.

Harveston, P. D. (2000): Synoptic versus Incremental Internationalization: An Examination of "Born Global" and "Gradual Globalizing" Firms. PhD Dissertation, University of Memphis.

Hoppner, J. J. - Griffith, D. A. (2015): Looking Back to Move Forward: A Review of the Evolution of Research in International Marketing Channels. Journal of Retailing, 91(4): 610-626.

Jarosiński, M. (2017): Wczesna internacjonalizacja polskich przedsiębiorstw (Early Internationalisation of Polish Firms). Research Report, SGH Warsaw School of Economics, Warsaw.

Johanson, J. - Vahlne. J. (1977): The Internationalization Process of the Firm: A Model of Knowledge Development and Increasing Foreign Commitments. Journal of International Business Studies (Spring/Summer): 23-32.

Kozarzewski, P. - Bałtowski, M. (2017): Change in the Ownership Policy Paradigm in Poland: State Control vs. Privatisation. Acta Oeconomica, 67(1): 1-20.

Kowalik, I. - Danik, L. - Sikora T. (2017): Entrepreneurial Orientation Elements in the Polish International New Ventures. Baltic Journal of Management, 12(2): 194-213.

McDougall, P. - Shane, S. - Oviatt, B. M. (1994): Explaining the Formation of International New Ventures: The Limits of Theories from International Business Research. Journal of Business Venturing, 9(6): 469-487.

McNaughton, R. B. (2003): The Number of Export Markets that a Firm Serves: Process Models versus the Born-Global Phenomenon. Journal of International Entrepreneurship, 1(3): 297-311.

Moen, Ø. (2002): The Born Globals. A New Generation of Small European Exporters. International Marketing Review, 19(2):156-175.

Moen, Ø. - Servais, P. (2002): Born Global or Gradual Global? Examining the Export Behavior of Small and Medium-Sized Enterprises. Journal of International Marketing, 10(3): 49-72.

Monaghan, S. - Tippmann, E. (2018): Becoming a Multinational Enterprise: Using Industry Recipes to Achieve Rapid Multinationalization. Journal of International Business Studies, 49: 473495.

Nayyar, P. R. (1993): On the Measurement of Competitive Strategy: Evidence from a Large Multiproduct US Firm. Academy of Management Journal, 36(6): 1652-1669.

Neubert, M. (2017): International Pricing Strategies for Born-Global Firms. Central European Business Review, 6(03): 41-50.

Nowinski, W. - Rialp, A. (2013): Drivers and Strategies of International New Ventures from a Central European Transition Economy. Journal for East European Management Studies, 18(2): 191-231.

Peńa-Vinces, J. C. - Acedo, F. J. - Roldán, J. L. (2014): Model of the International Competitiveness of SMNEs for Latin American Developing Countries. European Business Review, 26(6): $552-567$. 
Pett, L. - Francis, J. D. - Wolff, J. A. (2004): Examining SME Internationalization Motives as an Extension of Competitive Strategies. Journal of Business and Entrepreneurship, 16(1): 46-65.

Porter, M. (1980): Competitive Strategy. New York: Free Press.

Rialp, A. - Rialp J. - Urbano, D. - Vaillant, Y. (2005): The Born-Global Phenomenon: A Comparative Case Study Research. Journal of International Entrepreneurship, 3: 133-171.

Roth, K. - Morrison, A. J. (1992): Business-Level Competitive Strategy: A Contingency Link to Internationalization. Journal of Management, 18(3): 473-487.

Rua, A. - França, A. - Ortiz, R. F. (2017): Key Drivers of SMEs Export Performance: The Mediating Effect of Competitive Advantage. Journal of Knowledge Management, 22(2): 257-279.

Sikora, T. - Baranowska-Prokop, E. (2018): Explaining Success Perception of Polish International New Ventures: Four Perspectives. Economics and Sociology, 11(4): 106-127.

Śliwiński, R. (2012): Internationalization Strategies of Polish Fast Growing Enterprises. Poznań University of Economics Review, 12(1): 17-39.

Trąpczyński, P. (2013): From Going International to Being International - Strategies for International Competitiveness. Poznań University of Economics Review, 13(1): 89-114.

Yin, R. K. (2009): Case Study Research - Design and Methods. Thousand Oaks: Sage Publications. 